\title{
Pemetaan Publikasi Riset Perdagangan Internasional dengan Pendekatan Studi Bibliografi
}

\author{
Angestika Wilandari \\ Universitas Bina Sarana Informatika \\ e-mail: angestika.ael@bsi.ac.id

\begin{tabular}{ccc}
\hline Diterima & Direvisi & Disetujui \\
$27-08-2021$ & $01-09-2021$ & $02-09-2021$ \\
\hline
\end{tabular}

\begin{abstract}
Abstrak - Penelitian ini bertujuan untuk memetakan perkembangan studi atau penelitian dengan tema perdagangan internasional yang menjadi salah satu indikator perkembangan ekonomi suatu negara. Waktu pengamatan diambil dari tahun 2015-2020 dengan mengambil sampel jurnal sebanyak empat jurnal terakreditasi Sinta 1 dan Sinta 2. Artikel yang dijadikan sampel dari empat jurnal tersebut mencapai 44 artikel dengan sistem seleksi artikel yang dibahas dalam metode penelitian. Penelitian ini mengklasifikasikan baik artikel atau jurnal menjadi klasifikasi berdasarkan topik penelitian, klasifikasi berdasarkan metode penelitian, serta klasifikasi berdasarkan tahun terbit. Topik yang paling banyak diteliti berdasarkan artikel sampel adalah gabungan variabel anteseden dan konsekuensi. Sedangkan untuk metode yang paling banyak digunakan adalah metode penelitian analytical serta tidak ada satu pun artikel yang menggunakan metode review. Dilanjutkan dengan tahun terbit, diketahui bahwa periode 2015-2016 merupakan periode tahun dengan artikel bertema perdagangan internasional yang paling banyak diterbitkan. Penelitian ini diharapkan dapat dijadikan referensi untuk penelitian selanjutnya dengan menambahkan faktor lain seperti klasifikasi variabel penelitian yang masuk ke dalam kategori anteseden ataupun konsekuensi, serta faktor tambahan analisis sitasi.
\end{abstract}

Kata Kunci: Anteseden dan Konsekuensi, Perdagangan Internasional, Studi Bibliografi

\begin{abstract}
This study aims to map the development of studies or research with the theme of international trade which is one of the indicators of a country's economic development. The time of observation was taken from 2015 2020 by taking a sample of four journals accredited by Sinta 1 and Sinta 2. The articles sampled from the four journals reached 44 articles with an article selection system discussed in the research method. This study classifies articles or journals into classifications based on research topics, classifications based on research methods, and classifications based on year of publication. The most studied topic based on sample articles is a combination of antecedent and consequence variables. Meanwhile, the most widely used method is the analytical research method and there is not a single article that uses the review method. Followed by the year of publication, it is known that the 2015-2016 period is the period of year with the most published articles on international trade themes. It is hoped that this research can be used as a reference for further research by adding other factors such as the classification of research variables that fall into the antecedent or consequence category, as well as additional factors of citation analysis.
\end{abstract}

Keywords : Antecedents and Consequences, Bibliographic Studies, International Trade

\section{PENDAHULUAN}

Perkembangan penelitian dilandasi dengan berkembangnya teori perdagangan internasional dari waktu ke waktu. Konsep perdagangan bebas pertama kali diusung oleh Adam Smith yang kemudian dikembangkan oleh David Ricardo pada tahun 1887 (Yusdja, 2016). Penjajahan masih terjadi di era tersebut dengan menuai pro dan kontra terhadap praktik perdagangan bebas atau perdagangan internasional. Prinsip dasar dari teori David Ricardo adalah setiap negara dapat melakukan perdagangan dengan menerapkan spesialisasi produksi sehingga tujuan utama dari perdagangan internasional yaitu kesejahteraan masyarakat dapat tercapai (Yusdja,
2016).

Perkembangan penelitian mengenai perdagangan internasional rata-rata bersifat empiris atau melihat pengaruh serta sebab akibat atas faktor tertentu terhadap perdagangan internasional. Penelitian yang bersifat review belum ditemukan sehingga menarik minat peneliti dalam penelitian ini untuk melakukan studi bibliografi bertemakan perdagangan internasional.

Herawati \& Bandi (2017) melakukan studi bibliografi atau literatur review untuk studi perpajakan dalam akuntansi dengan periode penelitian selama 20 tahun. Jurnal yang dijadikan sampel dalam penelitian tersebut sebanyak tujuh jurnal nasional terakreditasi. Menggunakan tujuh jurnal tersebut, Herawati \& Bandi 
(2017) mendapatkan 83 artikel sampel dengan periode amatan tahun 1997-2016.

Dalam penelitiannya, Herawati \& Bandi (2017) membagi klasifikasi menjadi klasifikasi artikel serta klasifikasi jurnal. Klasifikasi artikel yang dilakukan mengerucut kepada topik penelitian, metode peneltian, serta klasifikasi disiplin sumber. Untuk topik penelitian, Herawati \& Bandi (2017) mengklasifikasikan sesuai judul atau topik besar penelitian. Sedangan untuk metode penelitian, Herawati \& Bandi (2017) mengelompokkan berdasakan metode kuantitatif, kualitatif, dan metode campuran. Sedangkan untuk klasifikasi disiplin sumber dibagi menjadi disiplin sumber psikologi, sosiologi, ekonomi, spiritualitas, dan sistem informasi.

Selanjutnya dilakukan klasifikasi jurnal dengan tidak ada pembeda dengan perlakuan klasifikasi artikel. Namun pada klasifikasi jurnal berdasarkan metode penelitian, Herawati \& Bandi (2017) membagi klasifikasi jurnal menjadi kelompok eksperimen, survei, archival, kajian pustaka, studi kasus, deskriptif, interpretif, dan fenomenologi.

Hasil dari studi bibliografi Herawati \& Bandi (2017) adalah metode penelitian yang paling dominan digunakan dalam klasifikasi artikel adalah metode penelitian kuantitatif dengan topik penelitian berkisar kepada akuntansi keuangan, keperilakuan, dan evaluas kebijakan. Berdasarkan klasifikasi jurnal metode penelitian, metode yang paling sering digunakan adalah archival, survei, serta kajian pustaka. Semua jurnal didominasi oleh displin sumber ekonomi dengan analisis sitasi menunjukkan hampir setengah penelitian perpajakan sudah berkontribusi terhadap ilmu perpajakan dan akuntansi.

Studi bibliografi selanjutnya dilakukan oleh Suryaputra et al. (2017) dengan mendeskripsikan perkembangan penelitian kinerja perbankan di Indonesia dari 12 jurnal terakreditasi mewakili provinsi Jawa dan Bali. Tahun studi penelitian diambil dari periode 2002-2017 dengan sampel sebanyak 37 artikel.

Dalam penelitiannya, Suryaputra et al. (2017) menggunakan metode penelitian charting the field yang dilakukan oleh Hesford et al. (2007). Charting the field yang dimaksud melakukan klasifikasi artikel dan jurnal berdasarkan topik serta metode penelitian. Klasifikasi berdasarkan topik penelitian terbagi menjadi variabel anteseden dan variabel konsekuensi. Variabel konsekuensi merupakan variabel yang membahas faktor terjadinya suatu kejadian, dalam studi Suryaputra et al. (2017) adalah faktor terjadinya kinerja perbankan. Sedangkan variabel konsekuensi dapat dikatakan sebagai variabel yang dipengaruhi atau mempengaruhi. Variabel konsekuensi dalam studi Suryaputra et al. (2017) mencakup faktor apa saja yang dipengaruhi oleh kinerja perbankan.

Pembagian variabel anteseden dan konsekuensi dalam penelitian Suryaputra et al. (2017) sangat rinci. Sehingga untuk topik selain anteseden dan konsekuensi, dikelompokkan ke dalam topik lainnya seperti kebangkrutan bank, kesehatan bank, kepemilikan saham, dan lain-lain.
Selanjutnya Suryaputra et al. (2017) kembali melakukan klasifikasi artikel dan jurnal berdasarkan metode penelitian. Klasifikasi metode penelitian dibagi menjadi tiga kelompok yaitu analytical, survey, serta literature review. Hasil dari studi Suryaputra et al. (2017) menunjukkan topik yang paling banyak diteliti adalah topik anteseden dari kinerja bank, dengan metode analytical, serta variabel return on asset (ROA).

Studi bibliografi berikutnya untuk tema penelitian tertentu dilakukan oleh Dewi et al. (2018). Penelitian tersebut bertujuan untuk memberikan gambaran mengenai perkembangan penelitian pengungkapan informasi perusahaan di Indonesia (Dewi et al., 2018). Periode studi atau penelitian dimulai dari tahun 2004 hingga 2017 dengan menggunakan sebelas jurnal nasional yang telah terakreditasi. Artikel yang dijadikan sampel dalam penelitian tersebut mencapai 66 artikel.

Tidak berbeda dengan studi Suryaputra et al. (2017), Dewi et al. (2018) melakukan klasifikasi artikel serta jurnal berdasarkan topik serta metode penelitian. Adapun tambahan klasifikasi yang dilakukan untuk klasifikasi artikel adalah penambahan klasifikasi populasi penelitian serta klasifikasi model pengungkapan. Klasifikasi berdasarkan topik untuk artikel dan jurnal dibagi menjadi variabel anteseden dan variabel konsekuensi. Sedangkan untuk klasifikasi berdasarkan metode penelitian untuk artikel dan jurnal terbagi menjadi analytical, survey, serta literature review.

Klasifikasi selanjutnya merupakan klasifikasi tambahan berupa klasifikasi populasi penelitian serta klasifikasi model penelitian. Dewi et al. (2018) membagi klasifikasi populasi penelitian menjadi 16 populasi yaitu perusahaan manufaktur, perusahaan yang terlisting di BEI, perusahaan perbankan, perusahaan non keuangan, perusahaan IPO, perusahaan telekomunikasi asia pasifik, perusahaan sector riil, perusahaan perbankan syariah, perusahaan publik indeks LQ-45, perusahaan jasa, perusahaan keuangan, perusahaan perserta proper, perusahaan rokok, organisasi pengelola zakat, perusahaan di Malaysia, serta perusahaan terdaftar di Jakarta Stock Exchange.

Sedangkan untuk klasifikasi model pengungkapan, diketahui bahwa model pengungkapan yang paling banyak diteliti adalah pengungkapan Corporate Social Responsibility (CSR), pengungkapan wajib dan sukarela, serta pengungkapan Intellectual Capital.

Hasil studi Dewi et al. (2018) menunjukkan topik yang paling banyak diteliti adalah topik anteseden dari praktik pengungkapan informasi perusahaan sebanyak $43 \%$. Kemudian metode yang paling banyak digunakan adalah analytical dengan persentase sebesar $89 \%$. Terkait dengan model pengungkapan, diketahui bahwa model yang paling banyak digunakan adalah model pengungkapan Corporate Social Responsibility (CSR).

Studi terbaru yang terbit di tahun 2021 mengenai perkembangan penelitian tertentu kembali 
dilakukan oleh Saputri (2021). Penelitian dengan judul "Topik Balance Scorecard Dalam Literatur Akuntansi di Indonesia: Studi Bibliografi” kembali menggunakan metode charting the field. Menggunakan artikel sampel sebanyak 24 artikel yang didapat dari tujuh jurnal terakreditasi Sinta 2 dan Sinta 3 dilakukan untuk periode pengamatan dari tahun 2009 hingga 2019.

Klasifikasi yang dilakukan untuk artikel dan jurnal terbagi atas klasifikasi topik, metode, serta tahun terbit. Klasifikasi topik dilakukan dengan membagi varibel menjad anteseden dan konsekuensi, kemudian klasifikasi metode terbagi menjadi analytical dan survei. Sedangkan klasifikasi tahun terbit hanya melihat distribusi terbitnya artikel dalam jurnal penerbit setiap tahun.

Hasil dari penelitian Saputri (2021) menunjukkan topik penelitian dalam artikel sampel didominasi oleh artikel konsekuensi dengan persentase sebesar $79.17 \%$. Kemudian untuk metode yang paling banyak digunakan adalah analytical dengan persentase $66.67 \%$. Selanjutnya tahun yang yang paling banyak menerbitkan artikel dengan tema balance scorecard terdapat pada tahun 2013.

Mengacu kepada penelitian-penelitian sebelumnya, belum terdapat studi bibliografi yang membahas tema perdagangan internasional sebagai salah satu indikator pertumbuhan ekonomi suatu negara. Penelitian ini termotivasi oleh penelitian Saputri (2021) mengenai bibliografi penelitian, meskipun tidak mengangkat tema penelitian yang sama.

Penelitian ini mencoba mengkaji metode yang dilakukan oleh Saputri (2021) dengan mengadaptasi Hesford et al. (2007). Pada saat ini dengan adanya globalisasi membawa perubahan yang pesat pada perkembangan perdagangan internasional. Para ahli kemudian melakukan penelitian yang pada akhirnya dilakukan publikasi ilmiah. Beragamnya hasil publikasi mempermudah pemahaman serta aplikasi dari hasil penelitian tersebut. Sehingga perlu dilakukan pemetaan dengan membuat bibliografi dari penelitian-penelitian berjudul perdagangan internasional yang dilihat dari topik, metode, dan tahun terbit. Berdasarkan perkembangan tersebut, perlu dilakukan penelitian pemetaan publikasi riset penelitian perdagangan internasional dengan pendekatan studi bibliografi. Studi atau penelitian ini mencoba mendeskripsikan perkembangan penelitian mengenai tema perdagangan internasional dengan rentang waktu penelitian 2015-2020 mengingat di rentang waktu tersebut kondisi perdagangan internasional Indonesia mengalami perbaikan.Kondisi tersebut diasumsikan menarik minat peneliti untuk melakukan penelitian terkait perdagangan internasional. Karena keterbatasan sumber daya peneliti, maka waktu pengamatan hanya dibatasi selama lima tahun dengan memperhatikan aspekaspekserta asumsi penting dalam penelitian. Dalam perkembangannya, diharapkan melalui penelitian ini dapat dikembangkan untuk melihat kontribusi penelitian perdagangan internasional terhadap ilmu ekonomi. Selain itu diperjelas oleh Nurhayati \& Elly
(2017) bahwa dengan bibliografi dapat menunjukkan kegiatan yang dilakukan oleh para peneliti. Sehingga dengan adanya studi bibliografi mengenai perdagangan internasional diharapkan dapat dijadikan bahan rujukan oleh peneliti lain yang ingin mengembangkan studi bibliografi bertemakan perdagangan internasional.

\section{METODE PENELITIAN}

Metode yang digunakan dalam penelitian ini dikembangkan oleh Hesford et al. (2007) yaitu "charting the field". Mengacu kepada Dewi et al., (2018) peneliti memilih penelitian dengan topik perdagangan internasional pada empat jurnal terakreditasi dengan rincian satu jurnal di Sinta 1 dan tiga jurnal di Sinta 2. Adapun sampel jurnal yang terdapat pada jurnal terakreditasi Sinta 1 dan Sinta 2 hanya terdapat empat jurnal yang memiliki ruang lingkup ekonomi atau ekonomi internasional. Daftar nama jurnal yang dijadikan sampel dalam penelitian dapat dilihat pada Tabel 1.

Tabel 1. Daftar Nama Jurnal

\begin{tabular}{clccc}
\hline No & Nama Jurnal & Institusi & $\begin{array}{c}\text { Total } \\
\text { Artikel }\end{array}$ & $\begin{array}{c}\text { Indeks } \\
\text { sinta }\end{array}$ \\
\hline 1 & $\begin{array}{l}\text { Economic } \\
\text { Journal of } \\
\text { Emerging } \\
\text { Markets }\end{array}$ & $\begin{array}{c}\text { Universitas } \\
\text { Islam }\end{array}$ & 108 & 1 \\
& Indonesia & & \\
\hline 2 & Journal of & Binus & 60 & 2 \\
& $\begin{array}{l}\text { ASEAN } \\
\text { Studies }\end{array}$ & University & & \\
\hline 3 & $\begin{array}{l}\text { Economics } \\
\text { Development } \\
\text { Analysis }\end{array}$ & Universitas & 285 & 2 \\
& Negeri & & \\
\hline 4 & $\begin{array}{l}\text { Journal } \\
\text { Journal of } \\
\text { Economics } \\
\text { and Policy } \\
\text { (JEJAK) }\end{array}$ & Universitas & 160 & 2 \\
& Nemarang & & \\
\hline
\end{tabular}

Sumber : Data Diolah (2021)

Pada Tabel 1 menggambarkan sampel dari daftar nama jurnal, namun tidak menggambarkan jumlah sampel artikel penelitian. Total artikel yang dijadikan sampel penelitian mencapai 44 artikel kemudian dikelompokkan berdasarkan topik dan metode penelitian. Kembali merujuk kepada Saputri (2021) pada penelitian ini juga menambahkan unsur tahun terbit pada klasifikasi artikel atupun jurnal.

Pemilihan jurnal dalam penelitian ini dilakukan berdasarkan kriteria berikut : 1) Jurnal merupakan jurnal terakreditasi dan terindeks SINTA 1 dan SINTA 2. 2) Jurnal dapat diakses secara daring. 3) Peneliti melakukan pemilihan artikel yang sesuai dengan topik perdagangan internasional.

Kriteria artikel yang dijadikan sampel penelitian dilakukan melalui penjelasan gambar di bawah berikut 


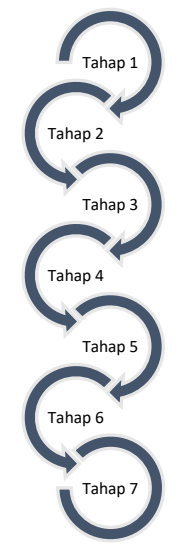

Sumber : Data diolah (2021)

Gambar 1. Alur Pemilihan Sampel

Penjelasan dari gambar di atas adalah sebagai berikut :1) Tahap 2 : Peneliti berfokus mencari jurnal yang sudah terindeks SINTA 1 dan SINTA 2. 2) Tahap 2 : Peneliti membuka satu persatu portal jurnal tersebut secara daring. 3) Tahap 3: Peneliti melakukan pengecekan setiap volume penerbitan artikel dimulai dari tahun 2015. 4) Tahap 4 : Pada saat melakukan pengecekan volume penerbitan artikel, peneliti berfokus melihat judul artikel yang bersangkutan dengan topik perdagangan internasional. 5) Tahap 5 : Apabila judul artikel tidak berkaitan dengan topik perdagangan internasional maka tidak dijadikan sampel penelitian. 6) Tahap 6 : Namun apabila judul artikel mengandung unsur topik perdagangan internasional, maka peneliti membuka file atau melakukan download artikel tersebut untuk diidentifikasi secara detail apakah layak dijadikan sampel penelitian. 7) Tahap 7: Setelah melakukan download artikel, peneliti kemudian melakukan tabulasi data berdasarkan judul penelitian, nama jurnal, periode dan tahun terbit, tahun penelitian, nama peneliti, metode penelitian, serta sifat artikel.

\section{HASIL DAN PEMBAHASAN}

Hasil dan pembahasan mencakup informasi sampel artikel yang kemudian dilanjutkan dengan klasifikasi artikel dan jurnal. Klasifikasi artikel dan jurnal yang dimaksud terbagi menjadi klasifikasi berdasarkan topik penelitian, klasifikasi berdasarkan metode penelitian, serta klasifikasi berdasarkan tahun terbit. Mengacu kepada penelitian-penelitian sebelumnya, klasifikasi artikel dilakukan dengan cara membagi-bagi artikel atau paper penelitian berdasarkan klasifikasi yang ditentukan. Sedangan klasifikasi jurnal membagi portal jurnal atau OJS sesuai dengan metode klasifikasi yang dilakukan pada klasifikasi artikel.

\section{Informasi Sampel Artikel}

Hasil dari penelitian ini menggunakan 44 artikel dari 4 jurnal terakreditasi dan sudah terindeks SINTA sesuai dengan kriteria. Adapun kelengkapan judul artikel, nama peneliti, tahun penelitian, nama jurnal, serta periode terbit dapat dilihat melalui Tabel 2. Mengacu kepada Saputri (2021) disebutkan pentingnya pemilihan rentang waktu penelitian, maka penelitian ini mengambil tahun penelitian sepanjang lima tahun bermula dari tahun 2015 hingga 2020. Peneliti memilih rentang waktu tersebut dengan alasan di tahun 2015 secara keseluruhan neraca perdagangan Indonesia dicatatkan membaik jika dibandingkan tahun-tahun sebelumnya (Indonesia, n.d.).Tren dari neraca perdagangan dapat dilihat melalui Grafik 1 . Sehingga penelitian dengan tema perdagangan internasional diharapkan kembali menjadi tema yang menarik untuk dibahas oleh kalangan peneliti.

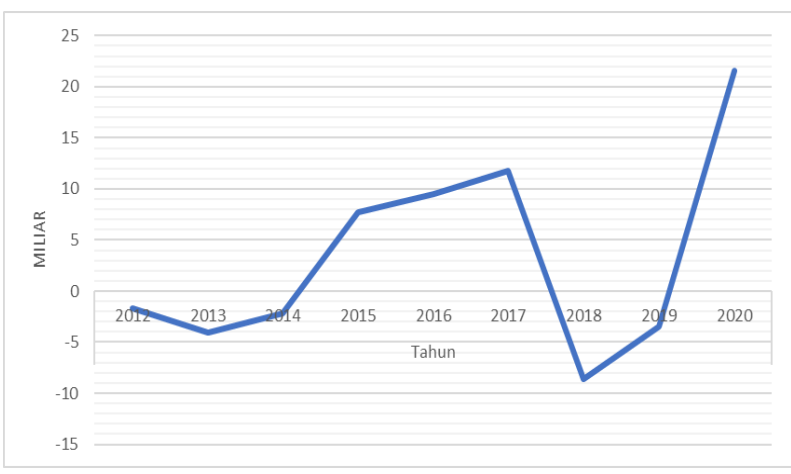

Sumber : Data Diolah (2021)

Grafik 1. Tren Neraca Perdagangan

Merujuk pada Tabel 2 diketahui bahwa untuk Economic Journal of Emerging Markets sepanjang tahun penelitian memiliki total penelitian sebanyak 108 artikel dengan 14 artikel di antaranya bertopik perdagangan internasional. Apabila diukur dalam persentase, artikel bertopik perdagangan internasional hanya sebesar $13 \%$. Selanjutnya untuk Journal of ASEAN Studies, dari 60 artikel yang dipublikasikan artikel dengan tema perdagangan internasional hanya berjumlah tiga artikel atau sebesar 5\%. Jurnal berikutnya yaitu Economics Development Analysis Journal mempunyai artikel terbit sebanyak 285 dengan 18 di antaranya bertemakan perdagangan internasional.

Secara persentase 18 artikel bertemakan perdagangan tersebut menduduki sebanyak $6 \%$ dari 285 artikel yang terpublikasi. Kemudian jurnal terakhir yang dijadikan sampel yaitu Journal of Economics and Policy (JEJAK) memiliki 160 artikel yang dipublikasi dengan $6 \%$ atau sembilan artike di dalamnya bertemakan perdagangan internasional. Dapat disimpulkan bahwa masih sedikit artikel bertema perdagangan internasional di rentang waktu penelitian, dengan Economic Journal of Emerging Markets yang mendominasi. 
Mengingat jurnal dengan status akreditasi Sinta 1, Economic Journal of Emerging Markets menjadi portal jurnal yang diminati oleh para peneliti. Meskipun demikian, persyaratan penelitian yang akan dipublikasikan menjadi tantangan tersendiri bagi peneliti. Berdasarkan penelusuran lebih lanjut melalui portal jurnal yang dijadikan sampel penelitian, penelitian dengan tema perdagangan internasional belum menjadi tema penelitian yang paling sering diangkat. Tema yang paling banyak diangkat adalah penelitian dengan tema ekonomi pembangunan, manajemen keuangan, atau ekonomi digital. Sebagaimana pada penelitian Ma'ruf \& Wihastuti (2008) disebutkan bahwa penelitian berkaitan dengan pembangunan serta pembangunan ekonomi sangat menarik untuk diperdebatkan. Selain itu dijelaskan oleh Kementrian Komunikasi dan Informasi (2019) bahwa ekonomi digital tumbuh sangat pesat sehingga menarik minat praktisi atau akademisi untuk terjun di dalamnya.

\section{Klasifikasi Berdasarkan Topik Penelitian}

Mengacu kepada Hesford et al. (2007), penelitian ini melakukan klasifikasi tiap artikel dan portal jurnal (OJS) berdasarkan topik serta metode penelitian.

\subsection{Klasifikasi Artikel}

Pengklasifikasian artikel mengenai topik penelitian perdagangan internasional dibedakan menjadi anteseden dan konsekuensi. Pengertian anteseden dan konsekuensi menurut penelitian sebelumnya seperti Suryaputra et al. (2017), Dewi et al. (2018), serta Saputri (2021) dijelaskan sebagai berikut : 1) Anteseden memiliki pengertian faktor-faktor apa saja yang menyebabkan terjadinya suatu penelitian, dalam konteks penelitian ini dapat diartikan sebagai faktor apa saja yang menyebabkan terjadinya perdagangan internasional baik dari segi ekspor ataupun impor. Kemudian 2) Konsekuensi memiliki pengertian dampak atau pengaruh atas kebijakan tertentu terhadap perdagangan internasional atau sebaliknya.

Selain klasifikasi artikel, juga dilakukan klasifikasi jurnal. Herawati \& Bandi (2017) dalam penelitiannya melakukan klasifikasi jurnal yang dibagi menjadi klasifikasi jurnal berdasarkan topik dan klasifikasi berdasarkan metode penelitian. Klasifikasi jurnal juga dilakukan dalam penelitian Suryaputra et al. (2017), Dewi et al. (2018), dan Saputri (2021). Sehingga dapat diketahui bahwa klasifikasi tidak terbatas hanya artikel saja, namun dapat diperluas dengan melakukan klasifikasi jurnal.

Tabel 2 menunjukkan klasifikasi artikel perdagangan internasional berdasarkan topik penelitian yang terjadi selama lima tahun.
Tabel 2. Klasifikasi Artikel Berdasarkan Topik Penelitian

\begin{tabular}{ccc}
\hline $\begin{array}{c}\text { Topik } \\
\text { Penelitian }\end{array}$ & Jumlah Artikel & Persentase \\
\hline Anteseden & 10 & $22.73 \%$ \\
\hline Konsekuensi & 15 & $34.09 \%$ \\
\hline $\begin{array}{c}\text { Anteseden dan } \\
\text { Konsekuensi }\end{array}$ & 19 & $43.18 \%$ \\
\hline Total & 44 & $100 \%$ \\
\hline
\end{tabular}

Sumber : Data Diolah (2021)

Berdasarkan Tabel 2 dapat disimpulkan bahwa dalam jangka waktu lima tahun penelitian mengenai perdagangan internasional dengan topik anteseden terdapat sebesar sepuluh artikel, penelitian dengan topik konsekuensi sebanyak 15 artikel, serta penelitian yang mengangkat topik anteseden dan konsekuensi terdapat 19 artikel. Kondisi tersebut mengindikasikan untuk penelitian perdagangan internasional didominasi oleh artikel yang membahas faktor terjadinya perdagangan internasional disertai dengan dampak atau pengaruhnya.Sehingga dapat ditarik kesimpulan bahwa penelitian dengan tema perdagangan internasional lebih mengedepankan kepada hasil analisis dibandingkan alur historis. Hasil dari analisis tersebut pada akhirnya akan menjadi rujukan-rujukan penelitian yang bermanfaat (Jamal, 2012).

\subsection{Klasifikasi Jurnal}

Klasifikasi jurnal berdasarkan topik penelitian tidak berbeda dengan klasifikasi artikel berdasarkan topik penelitian. Klasifikasi jurnal berdasarkan topik penelitian melihat artikel dengan topik anteseden serta konsekuensi. Rincian klasifikas jurnal sepanjang lima tahun penelitian (2015-2020) berdasarkan topik penelitian dapat dilihat melalui Tabel 3.

Tabel 3. Klasifikasi Jurnal Berdasarkan Topik Penelitian

\begin{tabular}{lccc}
\hline Nama Jurnal & \multicolumn{3}{c}{ Topik } \\
\cline { 2 - 4 } & $\mathrm{A}$ & $\mathrm{K}$ & $\mathrm{A} \& \mathrm{~K}$
\end{tabular}

\begin{tabular}{lccc}
\cline { 2 - 3 } & \multicolumn{3}{c}{ Jumlah } \\
\hline $\begin{array}{l}\text { Economic } \\
\text { Journal of }\end{array}$ & 7 & 2 & 5 \\
$\begin{array}{l}\text { Emerging } \\
\text { Markets }\end{array}$ & & \\
\hline $\begin{array}{l}\text { Journal of } \\
\text { ASEAN }\end{array}$ & 2 & 1 & 0 \\
Studies & & & \\
\hline Economics & 0 & 7 & 11 \\
\hline
\end{tabular}




\begin{tabular}{|c|c|c|c|}
\hline $\begin{array}{l}\text { Development } \\
\text { Analysis } \\
\text { Journal }\end{array}$ & & & \\
\hline $\begin{array}{l}\text { Journal of } \\
\text { Economics } \\
\text { and Policy } \\
\text { (JEJAK) }\end{array}$ & 1 & 5 & 3 \\
\hline Total & 10 & 15 & 19 \\
\hline
\end{tabular}

Sumber : Data Diolah (2021)

Tabel 3 di atas menggambarkan rincian klasifikasi jurnal berdasarkan topik penilitian. Namun dikarenakan keterbatasan tempat dalam insert tabel diketahui bahwa "A" memiliki arti anteseden, "K" memiliki arti konsekuensi, sedangkan "A \& K" memiliki arti anteseden dan konsekuensi.

Melalui Tabel 2 diketahui bahwa ada 10 artikel yang diterbitkan dengan tema perdagangan internasional dan bertopik anteseden. Apabila diintegrasikan dengan Tabel 3, terlihat distribusi atau persebaran jurnal yang menerbitkan sepuluh artikel bertopik anteseden. Economic Journal of Emerging Markets memiliki kontribusi sebesar $70 \%$ dalam penerbitan sepuluh artikel dengan topik anteseden. Di lain pihak terlihat tidak adanya artikel dengan topik anteseden yang diterbitkan oleh Economics Development Analysis Journal sepanjang 2015-2020.

Meskipun tidak adanya artikel yang diterbitkan oleh Economics Development Analysis Journal dengan tema anteseden, namun sebesar $46.67 \%$ artikel bertopik konsekuensi telah diterbitkan sepanjang tahun 20152020. Artikel dengan topik konsekuensi paling sedikit diterbitkan oleh Journal of ASEAN Studies dari tahun 2015 hingga 2020 yaitu sebanyak satu artikel.

Tidak hanya artikel dengan topik konsekuensi yang paling banyak diterbitkan oleh Economics Development Analysis Journal, diketahui bahwa sebanyak $57.89 \%$ artikel diterbitkan dengan topik anteseden dan konsekuensi pada jurnal tersebut. Berbanding terbalik dengan Economics Development Analysis Journal, tidak ada satu pun artikel yang diterbitkan oleh Journal of ASEAN Studies dengan topik anteseden dan konsekuensi di tahun 2015-2020. Kondisi pada Tabel 3 dapat disimpulkan adanya informasi yang diketahui jurnal penerbit apa saja yang menerbitkan artikel-artikel bertopik anteseden, konsekuensi, serta anteseden dan konsekuensi. Penghitungan klasifikasi jurnal pada Tabel 3 harus terintegrasi dengan klasifikasi artikel pada Tabel 3.

\section{Klasifikasi Berdasarkan Metode Penelitian}

Dewi et al. (2018) pada penelitiannya disebutkan bahwa artikel serta jurnal secara metode penelitian dapat diklasifikasikan menjadi artikel atau jurnal dengan metode analytical, metode review, serta metode survei. Namun apabila disesuaikan berdasarkan sampel yang diteliti, penelitian ini hanya membagi klasifikasi artikel dan jurnal dengan metode analyticaldan dengan metode review. Rincian mengenai jumlah klasifikasi artikel serta jurnal berdasarkan metode penelitian dapat dilihat melalui Tabel 4 dan Tabel 5.

\subsection{Klasifikasi Jurnal}

Tabel 4. Klasifikasi Artikel Berdasarkan Metode Penelitian

\begin{tabular}{ccc}
\hline Metode & Jumlah Artikel & Persentase \\
\hline Analytical & 40 & $90.91 \%$ \\
\hline $\begin{array}{c}\text { Analytical dan } \\
\text { Review }\end{array}$ & 4 & $9.09 \%$ \\
\hline Total & 44 & $100 \%$
\end{tabular}

\section{Sumber : Data Diolah (2021)}

Saputri (2021) dalam penelitiannya menjelaskan metode penelitian analytical dapat dibagi menjadi analisis kuantitatif dan kualitatif. Lebih lanjut Saputri (2021) menjelaskan bahwa penelitian dengan metode analisis adalah metode yang bersifat numerik, sedangan analisis kualitatif adalah penelitian dengan sifat nonnumerik.

Berdasarkan Tabel 4, artikel pada penelitian ini didominasi oleh artikel dengan metode penelitian analisis. Merujuk kepada tabulasi data yang dimiliki oleh peneliti dan merujuk kepada definisi penelitian analisis oleh Saputri (2021), artikel dengan topik perdagangan internasional sebesar $90.91 \%$ disajikan dengan metode analisis kuantitatif. Kemudian 0\% artikel disajikan dengan metode review, sedangkan artikel yang menggabungkan metode analisis dan review terdapat sebanyak 4 artikel selama lima tahun jangka waktu penelitian.

Hutagalung \& Utomo (2017) dalam penelitiannya menyebutkan metode penelitian yang paling banyak digunakan dalam penelitian adalah metode analisis kuantitatif. Kondisi tersebut dijelaskan dalam beberapa faktor yaitu: 1) Metode analisis kuantitatif jelas pada angka. 2) Pengolahan data dalam analisis kuantitatif lebih cepat dilakukan. 3) Referensi penelitian lebih banyak. Selain itu Martono (2014) dalam bukunya menyebutkan penelitian dengan metode analisis kuantitatif akan terbebas dari biaya penelitian yang mahal.

Mengacu kepada penelitian Hutagalung \& Utomo (2017), artikel penelitian bertemakan perdagangan internasional didominasi dengan metode analisis kuantitatif dikarenakan argumentasi kemudahan metode serta cepatnya pengolahan data. Selain itu penelitian bertemakan perdagangan internasional membutuhkan data penelitian yang memiliki cakupan luas. Sehingga penelitian dengan metode analisis kuantitatif cenderung dipilih oleh peneliti yang mengangkat tema perdagangan internasional. 


\subsection{Klasifikasi Jurnal}

Tabel 5. Klasifikasi Jurnal Berdasarkan Metode Penelitian

\begin{tabular}{cccc} 
Nama Jurnal & \multicolumn{3}{c}{ Metode } \\
\cline { 2 - 4 } & A & R & A \& R
\end{tabular}

\begin{tabular}{|c|c|c|c|}
\hline & \multicolumn{3}{|c|}{ Jumlah } \\
\hline $\begin{array}{l}\text { Economic } \\
\text { Journal of } \\
\text { Emerging } \\
\text { Markets }\end{array}$ & 14 & 0 & 0 \\
\hline $\begin{array}{l}\text { Journal of } \\
\text { ASEAN } \\
\text { Studies }\end{array}$ & 3 & 0 & 0 \\
\hline $\begin{array}{l}\text { Economics } \\
\text { Development } \\
\text { Analysis } \\
\text { Journal }\end{array}$ & 15 & 0 & 3 \\
\hline $\begin{array}{l}\text { Journal of } \\
\text { Economics } \\
\text { and Policy } \\
\text { (JEJAK) }\end{array}$ & 8 & 0 & 1 \\
\hline Total & 40 & 0 & 4 \\
\hline
\end{tabular}

Sumber : Data Diolah (2021)

Tidak berbeda dengan Tabel 3, adanya keterbatasan tempat dalam insert tabel maka pada kolom metode di Tabel 5 hanya diisi dengan "A", "R", serta "A \& R". Diketahui bahwa "A" memiliki arti analytical baik bersifak kualitatif ataupun kuantitatif, " $\mathrm{R}$ " memiliki arti review, sedangkan "A \& K" memiliki arti analytical dan review.

Pada Tabel 5 diketahui adanya integrasi antara Tabel 4 dan Tabel 5, di mana artikel dengan metode analytical diterbitkan oleh jurnal dengan jumlah 40 artikel dan seterusnya untuk metode review serta analytical dan review. Namun apabila melihat persebaran jurnal yang menerbitkan artikel dengan metode analytical, Economics Development Analysis Journal menerbitkan artikel terbanyak seesar $37.5 \%$. Apabila dilakukan analisis dengan melakukan tabulasi silang dengan Tabel 6, terlihat bahwa Economics Development Analysis Journal tidak menerbitkan artikel dengan topik anteseden. Sehingga artikel yang masuk dan diterbitkan oleh Economics Development Analysis Journal bersifat menjelaskan pengaruh atau sebab akibat dengan metode penelitian yang sangat analytical sehingga menghasilkan bukti empiris.

Kembali merujuk pada Tabel 5, terlihat bahwa tidak ada satu pun jurnal yang menerbitkan artikel dengan metode penelitian yang hanya bersifat review. Review sering diartikan dengan metode penelitian perbandingan literatur sehingga tidak menjelaskan fenomena atau pengaruh sebab akibat serta tidak menghasilkan bukti empiris. Kondisi tersebut sangat sulit dilakukan mengingat riset atau penelitian dengan tema perdagangan internasional akan sering membahas fenomena atau sebab akibat atas kebijakan tertentu terhadap perdagangan internasional. Pembahasan fenomena yang terjadi dalam ruang lingkup perdagangan internasional dapat berupa penjelasan faktor-faktor penyebab terjadinya perdagangan antarnegara, atau bersifat anteseden, namun tetap menggunakan pembangunan hipotesis serta pengujian empiris.

Meskipun penelitian atau riset mengenai perdagangan internasional lebih banyak dilakukan menggunakan metode analytical, namun tetap ada artikel yang menggunakan metode penelitian gabungan antara analytical dan review. Menurut telaah dan analisis yang dilakukan peneliti, ada empat artikel dengan metode penelitian gabungan antara analytical dan review. Empat artikel tersebut $75 \%$ dterbitkan oleh Economics Development Analysis Journal serta 25\% diterbitkan oleh Journal of Economics and Policy (JEJAK).

\section{Klasifikasi Berdasarkan Tahun Terbit}

Klasifikasi artikel serta jurnal yang digunakan dalam penelitian ini selain berdasarkan topik dan metode penelitian juga menggunakan klasifikasi berdasarkan tahun terbit. Klasifikasi berdasarkan tahun terbit dapat memberikan informasi berapa artikel dengan tema perdagangan internasional yang berhasil diterbitkan oleh jurnal sampel penelitian dalam jangka waktu penelitian (2015-2020). Rincian klasifikasi artikel serta jurnal berdasarkan tahun terbit dapat dilihat melalui Tabel 6 dan 7.

\subsection{Klasifikasi Artikel}

Tabel 6. Klasifikasi Artikel Tahun Terbit

\begin{tabular}{lll}
\hline Tahun Terbit & $\begin{array}{l}\text { Jumlah Artikel } \\
\text { Penelitian }\end{array}$ & Persentase \\
\hline 2015 & 9 & $20.46 \%$ \\
\hline 2016 & 7 & $15.90 \%$ \\
\hline 2017 & 8 & $18.19 \%$ \\
\hline 2018 & 9 & $20.46 \%$ \\
\hline 2019 & 4 & $9.09 \%$ \\
\hline 2020 & 7 & $15.90 \%$ \\
\hline Total & 44 & $100 \%$
\end{tabular}

Sumber : Data Diolah (2021)

Pada Tabel 6 di atas menunjukkan klasifikasi artikel berdasarkan tahun terbit tanpa mempertimbangkan jurnal yang menerbitkan. Artinya Tabel 6 di atas hanya melihat artikel berdasarkan tahun terbit dari tahun 2015 hingga 2020 untuk seluruh sampel jurnal. Diketahui bahwa tahun terbit dengan artikel paling sedikit yaitu sebesar $9.09 \%$ ada di tahun 
2019. Tidak diketahui secara pasti apakah di tahun 2019 sedikit dari akademisi serta peneliti yang melakukan penelitian bertemakan perdagangan internasional, atau ada kebijakan dari jurnal penerbit untuk tema artikel yang akan diterbitkan di tahun tersebut.

Namun apabila kembali merujuk pada argumentasi informasi artikel sampel, masih sedikitnya penelitian bertemakan perdagangan internasional dapat disebabkan minat penelitian dengan tema lain seperti ekonomi pembangunan serta ekonomi digital cenderung tinggi.

\subsection{Klasifikasi Jurnal}

Tabel 7. Klasifikasi Jurnal Berdasarkan Tahun Terbit

\begin{tabular}{cccc}
\hline Nama Jurnal & \multicolumn{3}{c}{ Tahun } \\
\cline { 2 - 4 } & $2015-$ & $2017-$ & $2019-$ \\
2016 & 2018 & 2020
\end{tabular}

\begin{tabular}{|c|c|c|c|}
\hline & \multicolumn{3}{|c|}{ Jumlah } \\
\hline $\begin{array}{l}\text { Economic } \\
\text { Journal of } \\
\text { Emerging } \\
\text { Markets }\end{array}$ & 3 & 3 & 8 \\
\hline $\begin{array}{l}\text { Journal of } \\
\text { ASEAN } \\
\text { Studies }\end{array}$ & 1 & 1 & 1 \\
\hline $\begin{array}{l}\text { Economics } \\
\text { Development } \\
\text { Analysis } \\
\text { Journal }\end{array}$ & 9 & 8 & 1 \\
\hline $\begin{array}{l}\text { Journal of } \\
\text { Economics } \\
\text { and Policy } \\
\text { (JEJAK) }\end{array}$ & 3 & 5 & 1 \\
\hline Total & 16 & 17 & 11 \\
\hline
\end{tabular}

Sumber : Data Diolah (2021)

Tabel 7 didapat dari data tabulasi yang dimiliki oleh peneliti. Dimulai dari Economic Journal of Emerging Markets dengan total penelitian sepanjang tahun 2015-2020 adalah sebanyak 108 artikel. Pada periode 2015-2020, artikel yang bertemakan perdagangan internasional hanya memiliki persentase $13 \%$ atau sebanyak 14 artikel. Dilanjutkan dengan Journal of ASEAN Studies, dari 60 artikel yang diterbitkan hanya tiga artikel bertemakan perdagangan internasional untuk periode 2015-2020. Persentase riset atau penelitian bertemakan perdagangan internasional yang diterbitkan oleh Journal of ASEAN Studies sebesar 5\% atau paling rendah dibandingkan jurnal sampel lain.

Jurnal ketiga yang menjadi sampel penelitian adalah Economics Development Analysis Journal, di mana jurnal tersebut memiliki periode terbit paling banyak yaitu empat kali dalam setahun. Dengan kondisi terbit yang lebih banyak dibandingkan junal sampel lain, tidak mengherankan bahwa total artikel yang diterbitkan sepanjang 2015-2020 mencapai 285 artikel dengan persentae $6 \%$ artkel yang bertemakan perdagangan internasional. Mengacu kepada jumlah artikel yang diterbitkan oleh Economics Development Analysis Journal, terdapat 18 artikel bertemakan perdagangan internasional yang diterbitkan tahun 2015-2020. Angka tersebut menunjukkan jurnal yang paling banyak menerbitkan artikel bertemakan perdagangan internasional dibandingkan jumlah sampel lainnya. Namun 18 artikel tersebut tidak cukup banyak apabila dipersentasekan, mengingat artikel yang terpublikasi selama lima tahun mencapai 285 artikel.

Sampel jurnal terakhir dalam penelitian ini yaitu Journal of Economics andPolicy (JEJAK). Dalam penghitungan dan tabulasi peneliti, dari tahun 2015 hingga 2020 terdapat 160 artikel yang diterbitkan dengan periode terbit dua kali dalam setahun. Apabila diurutkan berdasarkan total artikel atau penelitian yang telah dipublikasi tanpa melihat tema, Journal of Economics andPolicy (JEJAK) menduduki peringkat dua setelah Economic Development Analysis Journal. Dari 160 artikel tersebut hanya hanya $6 \%$ atau sebanyak Sembilan artikel yang membahas tema perdagangan internasional.

Apabila disimpulkan berdasarkan Tabel 7 maka diketahui untk periode 2017-2018 merupakan periode dengan artikel yang paling banyak diterbitkan bertemakan perdagangan internasional dengan jumlah 17 artikel. Menyusul kemudian di periode 2015-106 sebanyak 16 artikel, dan periode 2019-2020 sebanyak 11 artikel.

\section{KESIMPULAN}

Penelitian dengan tema perdagangan internasional didominasi oleh riset dengan topik bersifat anteseden dan konsekuensi. Artinya artikel yang terbit cenderung menggunakan topik faktor yang menyebabkan terjadinya perdagangan internasional dilanjutkan dengan pengaruh atau hubungan sebab akibat atas faktor tersebut. Topik tersebut akan berdampak pada luasnya informasi atas hasil dari riset dan penelitian yang dilakukan. Sehingga penelitian yang terjadi dapat memberikan nilai tambah untuk penelitian itu sendiri dan dapat dilanjutkan oleh penelitian berikutnya

Melihat klasifikasi jurnal dan artikel dari tahun terbit, terlihat distribusi yang tidak merata dari jumlah artikel terbit bertemakan perdagangan internasional. Seperti contoh Journal of ASEAN Studies, dengan pengelompokkan tahun 2015-2016, 2017-2018, 2019-2020 diketahui di masing-masing kelompok hanya terdapat satu artikel terbit bertemakan perdagangan internasional. Kondisi tersebut mengindikasikan bahwa ada di salah satu tahun artikel bertemakan perdagangan internasional tidak terbit. Tidak terbitnya artikel tersebut dapat diasumsikan dalam berbagai macam faktor.

Karena keterbatasan waktu dan sumber daya yang dimiliki oleh peneliti, penelitian ini dapat 
dikembangkan lebih lanjut oleh peneliti berikutnya dengan memperhatikan aspek-aspek seperti : 1) Analisis lebih lanjut apa saja variabel yang masuk ke dalam anteseden dan konsekuensi untuk masingmasing artikel. 2) Penambahan rentang waktu penelitian. 3) Menambahkan analisis sitasi untuk masing-masing artikel sampel. 4) Pembahasan faktor tidak terbitnya artikel perdagangan internasional dalam satu periode atau tahun penerbitan jurnal.

\section{REFERENSI}

Dewi, A. C., Fitriana, A., \& Setiawan, D. (2018). Perkembangan penelitian di bidang pengungkapan di Indonesia: Telaah konseptual. Jurnal Siasat Bisnis, 22(1), 1-19. https://doi.org/10.20885/jsb.vol22.iss1.art1

Herawati, N., \& Bandi, B. (2017). Dua Puluh Tahun Riset Perpajakan dalam Akuntansi: Suatu Studi Bibliografi. Jurnal Akuntansi Dan Keuangan, 19(2), https://doi.org/10.9744/jak.19.2.102-121

Hesford, J. W., Lee, S. H., Van der Stede, W. A., \& Young, S. M. (2007). Management Accounting: A BlibliographicStudy. In Handbook of Management Accounting Research (pp. 16-39). Elsevier Ltd.

Hutagalung, T., \& Utomo, D. (2017). Meta-Analisis Variasi Penelitian Dari Peneliti Akuntansi Di Indonesia. Diponegoro Journal of Accounting, 6(4), 352-362.

Indonesia, K. K. R. (n.d.). Neraca Perdagangan Indonesia 2015 Catatkan Surplus 7,52 Miliar Dolar AS. https://www.kemenkeu.go.id/publikasi/berita/n eraca-perdagangan-indonesia-2015-catatkansurplus-7-52-miliar-dolar-as/

Jamal, S. (2012). Merumuskan Tujuan dan Manfaat Penelitian. Ilmiah Dakwah Dan Komunikasi, 3 No. 5, 148-150.

Kementrian Komunikasi dan Informasi. (2019). Perkembangan Ekonomi Digital di Indonesia: Strategi dan Sektor Potensial. In Pusat Penelitian dan Pengembangan Aplikasi Informatika dan Informasi dan Komunikasi Publik Badan Penelitian dan Pengembangan SDM Kementerian Komunikasi dan Informatika.

Ma'ruf, A., \& Wihastuti, L. (2008). Pertumbuhan Ekonomi Indonesia: Determinan dan

$\begin{array}{lcr}\text { Prospeknya. Jurnal Ekonomi \& } & \begin{array}{r}\text { Studi } \\ \text { Pembangunan, }\end{array} & 9(1), \\ \text { https://doi.org/10.18196/jesp.9.1.1526 } & & \end{array}$

Martono, N. (2014). Metode Penelitian Kuantitatif Analisis Isi dan Analisis Data Sekunder (2nd ed.). PT RajaGrafindo Persada. https://books.google.co.id/books?id=tUl1BgA $\mathrm{AQBAJ} \&$ printsec $=$ frontcover $\# \mathrm{v}=$ onepage \&q\& $\mathrm{f}=$ false

Nurhayati, S., \& Elly, A. (2017). Terbitan Bibliografi Sebagai Alat Bantu Penelusuran Informasi Di Perpustakaan Pusat Penelitian Sosial Ekonomi Kelautan Dan Perikanan. Jurnal Pari, 2(2), 52. https://doi.org/10.15578/jp.v2i2.3249

Saputri, M. A. (2021). Topik Balance Scorecard Dalam Literatur Akuntansi Di Indonesia: Studi Bibliografi. Jurnal Akuntansi Trisakti, 0832, 61-78.

https://trijurnal.lemlit.trisakti.ac.id/jat/article/vi ew/8611

Suryaputra, F. A. G., Setiawan, D., \& Bandi. (2017). Perkembangan Penelitian Kinerja Perbankan Di Indonesia Filipus. Jurnal Akuntansi Dan Bisnis, 15(2), 96-105.

Yusdja, Y. (2016). Tinjauan Teori Perdagangan Internasional dan Keunggulan Kooperatif. Forum Penelitian Agro Ekonomi, 22(2), 126. https://doi.org/10.21082/fae.v22n2.2004.126141 